\title{
Oligometastasis and local ablation in the era of systemic targeted and immunotherapy
}

\author{
Rosario Mazzola', Barbara Alicja Jereczek-Fossa ${ }^{2,3}$, Davide Franceschini ${ }^{4}$, Slavisa Tubin ${ }^{5}$, Andrea Riccardo Filippi ${ }^{6}$, \\ Maria Tolia ${ }^{7}$, Andrea Lancia ${ }^{6}$, Giuseppe Minniti ${ }^{8}$, Stefanie Corradini ${ }^{9}$, Stefano Arcangeli ${ }^{10}$, Marta Scorsetti $^{4}$ \\ and Filippo Alongi ${ }^{1,11^{*}}$ (D)
}

\begin{abstract}
Background: During these last years, new agents have dramatically improved the survival of the metastatic patients. Oligometastases represent a continuous field of interest in which the integration of metastases-directed therapy and drugs could further improve the oncologic outcomes.

Herein a narrative review is performed regarding the main rationale in combining immunotherapy and target therapies with SBRT looking at the available clinical data in case of oligometastatic NSCLC, Melanoma and Kidney cancer.

Material and method: Narrative Review regarding retrospective and prospective studies published between January 2009 to November 2019 with at least 20 patients analyzed.

Results: Concerning the combination between SBRT and Immunotherapy, the correct sequence of remains uncertain, and seems to be drug-dependent. The optimal patients' selection is crucial to expect substantial benefits to SBRT/ Immunotherapy combination and, among several factors. A potential field of interest is represented by the so-called oligoprogressed disease, in which SBRT could improve the long-term efficacy of the existing target therapy.
\end{abstract}

Conclusions: A low tumor burden seems to be the most relevant, thus making the oligometastatic disease represent the ideal setting for the use of combination therapies with immunological drugs.

Keywords: Oligometastasis, Immunotherapy, Target therapy, Metastases-directed therapy

\section{Background}

The term oligometastases is referred to a limited tumor burden potentially amenable to local approaches. In this last clinical scenario, high-dose radiation therapy, also known as stereotactic body radiotherapy (SBRT), represents a viable treatment option able to modify the natural history of the oligometastatic disease [1-5].

\footnotetext{
* Correspondence: filippo.alongi@sacrocuore.it

${ }^{1}$ IRCCS, Advanced Radiation Oncology Department, Sacro Cuore Don

Calabria Hospital, Negrar di Valpolicella, Verona, Italy

${ }^{11}$ University of Brescia, Brescia, Italy

Full list of author information is available at the end of the article
}

During these last years, new agents have dramatically improved the survival of metastatic patients. Melanoma, Kidney and NSCLC represent the oncologic diseases in which targeted drugs and/or immunotherapy are changing the daily clinical practice. The rationale in combining targeted agents and/or immunotherapy with SBRT could be to improve the therapeutic ratio through increased tumor cell killing while maintaining stable or decreased toxicity [6]. Compared to conventionally fractionated radiotherapy, SBRT induces direct tumor vascular-endothelial damage that may enhance the delivery of targeted agents to the tumor [7-9]. All these effects seem to be SBRT-related appearing exclusively

(c) The Author(s). 2020 Open Access This article is licensed under a Creative Commons Attribution 4.0 International License, which permits use, sharing, adaptation, distribution and reproduction in any medium or format, as long as you give appropriate credit to the original author(s) and the source, provide a link to the Creative Commons licence, and indicate if changes were made. The images or other third party material in this article are included in the article's Creative Commons licence, unless indicated otherwise in a credit line to the material. If material is not included in the article's Creative Commons licence and your intended use is not permitted by statutory regulation or exceeds the permitted use, you will need to obtain permission directly from the copyright holder. To view a copy of this licence, visit http://creativecommons.org/licenses/by/4.0/ The Creative Commons Public Domain Dedication waiver (http://creativecommons.org/publicdomain/zero/1.0/) applies to the data made available in this article, unless otherwise stated in a credit line to the data. 
using larger fraction-doses, while are not found with conventionally fractionated radiotherapy. Targeting agents are directed against specific molecular mutations, aberrant intracellular signaling or repair pathways, negatively affecting carcinogenesis and tumor growth. If combined with radiation, these "smart drugs" might boost tumor responses to SBRT through those specific mechanisms they exert. Example of a highly rational combination would be synergistic anti-angiogenic effects of bevacizumab, which inhibits the development of tumor vasculature by targeting VEGF, and fulminant tumor vascular-endothelial damage induced by SBRT.

A combination of radio-immunotherapy originates from the significant immune-stimulatory effects they both exert boosting the natural antitumor immune response through synergistic potentiation of an immunomodulatory effect, possibly leading to an abscopal effect. This radiation-induced immune-mediated but rare systemic antitumor phenomenon that has high therapeutic potential, is more probable if induced by SBRT associated to checkpoint inhibitors $[10,11]$. SBRT, through released neo-antigens and consequent maturation and proliferation of naive T-cells, and immunotherapy through activation and amplification of naive T-cells, may reciprocally potentiate each other amplification of T-cells-mediated tumoricidal effects (mixed synergisticadditive effects) [12-14]. The lack of evidence prevents us from understanding which would be the finest timesequencing of radio-immunotherapy, and which radiation dose-fractionation would be most "immunogenic". It seems that concurrent treatment or close sequencing of immunotherapy following radiotherapy may take the most immunogenic advantage [12]. While the radiation dose required for the maximum local tumor-control has to be the highest reasonably achievable, for the strongest antitumor immune response should not necessarily be that high, but rather a sub-tumoricidal dose. Several preclinical studies suggested doses 8 to 10Gy per fraction in $1-3$ fractions to be optimally immunogenic [12-14].

Herein a narrative review is performed regarding the main rationale in combining immunotherapy and target therapies with SBRT looking at the available clinical data in case of oligometastatic NSCLC, melanoma and kidney cancers.

Retrospective and prospective studies published between January 2009 to November 2019 with at least 20 patients were analyzed.

\section{Oligometastatc non-small-cell lung cancer Immunotherapy and high doses RT}

Most of the available data are retrospective experiences on patients with brain oligorecurrence treated with radiosurgery (SRS) or hypofractionated RT. Chen et al. analyzed 37 NSCLC patients treated with SRS for brain metastases in combination with different checkpoint inhibitors. Data on these patients are enclosed in a larger series analyzing also patients with melanoma and renal cancer. Interestingly, the authors demonstrated that patients receiving RT concomitantly with immunotherapy had a longer OS (24.7 months) if compared with patients receiving both treatments but not concurrently (14.5 months). No increased rates of immune-related adverse events or acute neurologic toxicity were reported [15]. No safety concerns came also from a recent study by Verma et al. of thoracic RT combined with immunotherapy. In the 60 patients treated with $50 \mathrm{~Gy} / 4$ fractions or 60 Gy/10 fractions and concurrent Ipilimumab or Pembrolizumab, no patient experienced grade 4 adverse events, while 34 grade 3 events in a total of 15 patients were recorded. No difference in terms of toxicity was detected in patients receiving pembrolizumab or ipilimumab. Efficacy data are pending [16].

Concerning prospective data, two phase II trials combining RT and IT were recently published.

The Pembro-RT trial [17] enrolled NSCLC patients with at least 2 metastases (upper limit was not specified). Patients were randomized to receive Pembrolizumab or Pembrolizumab + SBRT to a single metastatic site, in order to increase the likelihood of abscopal effect. The dose chosen for SBRT was 24 Gy in 3 fractions, based on preclinical data suggesting that this schedule could increase the synergism between RT and the immune system [18]. The primary endpoint of the study was not reached, however experimental arm performed better than control arm for all endpoints. Objective response rate at 12 weeks was doubled ( $36 \%$ vs $18 \%$ ), median PFS and OS were also improved (6.6 months and 15.9 months respectively). Addition of SBRT to Pembrolizumab did not increase toxicity.

Bauml et al. [19] conducted a single arm phase II trial specifically focused on oligometastatic NSCLC (less than 4 metastatic sites) patients treated with local ablative therapies (including SBRT in 30 patients) on all sites and Pembrolizumab. Median PFS from local therapy was 19.1 months and median PFS from starting of Pembrolizumab was 18.7 months. Both results were significantly better than the historical control reporting a PFS of 6.6 months. Overall survival rate at 12 and 24 months was 90.9 and $77.5 \%$. Again, no safety concern emerged.

A summary of the main studies combining high dose $\mathrm{RT}$ and immunotherapy is reported in Tables 1 and 2.

\section{Target therapy and high doses $R T$}

A phase II study enrolled 24 unselected NSCLC patients with six or fewer sites of extracranial progression after first line chemotherapy. All were then treated with Erlotinib and SBRT, obtaining a median PFS and OS of 14.7 
Table 1 Patients and tumor characteristic of the selected studies

\begin{tabular}{|c|c|c|c|c|c|c|c|c|c|}
\hline $\begin{array}{l}\text { Authors } \\
\text { (year of } \\
\text { publication) } \\
\text { [Reference] }\end{array}$ & $\begin{array}{l}\text { Number } \\
\text { of patients } \\
\text { underwent } \\
\text { SBRT }\end{array}$ & $\begin{array}{l}\text { Type of } \\
\text { Study }\end{array}$ & $\begin{array}{l}\text { Primary } \\
\text { Tumor } \\
\text { site }\end{array}$ & $\begin{array}{l}\text { Number of } \\
\text { metastases } \\
\text { underwent to } \\
\text { SBRT (upper } \\
\text { limit) }\end{array}$ & $\begin{array}{l}\text { Type of } \\
\text { oligometastases } \\
\text { and organ involved } \\
\text { (liver, lung, bone, } \\
\text { nodes, brain...) }\end{array}$ & $\begin{array}{l}\text { Metastases } \\
\text { size } \\
(\mathrm{cm})\end{array}$ & $\begin{array}{l}\text { Median } \\
\text { total dose/ } \\
\text { fraction }\end{array}$ & $\begin{array}{l}\text { Biologically } \\
\text { equivalent } \\
\text { dose (Median } \\
\text { value) }^{\mathrm{a}}\end{array}$ & $\begin{array}{l}\text { Systemic } \\
\text { Therapy }\end{array}$ \\
\hline $\begin{array}{l}\text { Theelen et al. } \\
\text { (2019) [17] }\end{array}$ & 35 & Phase II & NSCLC & 1 & $\begin{array}{l}\text { Immunostimulation } \\
\text { (Lung, Nodes, Adrenal, } \\
\text { Bone, Skin, Liver, Pleura) }\end{array}$ & N.S. & $24 / 3$ & 43.2 & Pembrolizumab \\
\hline $\begin{array}{l}\text { Lesueur et al. } \\
\text { (2018) [20] }\end{array}$ & 28 & Retrospective & $\mathrm{NSCLC}$ & 1 & Oligorecurrent (Bone, Brain, Lung) & N.S. & $25-30 / 1-3$ & $81.6 / 60$ & Nivolumab \\
\hline $\begin{array}{l}\text { Chen et al. } \\
\text { (2018) [15] }\end{array}$ & 37 & Retrospective & $\mathrm{NSCLC}$ & 2 & Olicorecurrent (Brain) & N.S. & $\begin{array}{l}24-24-25 / \\
1-3-5\end{array}$ & $81.6 / 38.4 / 37.5$ & $\begin{array}{l}\text { Ipilimumab/ } \\
\text { Nivolumab/ } \\
\text { Pembrolizumab }\end{array}$ \\
\hline $\begin{array}{l}\text { Schapira et al. } \\
\text { (2017) [21] }\end{array}$ & 37 & Retrospective & NSCLC & 7 & Oligorecurrent (Brain) & 0.6 & $\begin{array}{l}18-17-21 / \\
1-1-3\end{array}$ & $50.4 / 45.9 / 35.7$ & $\begin{array}{l}\text { Nivolumab/ } \\
\text { Atezolizumab/ } \\
\text { Pembrolizumab }\end{array}$ \\
\hline $\begin{array}{l}\text { Bauml et al. } \\
\text { (2019) [19] }\end{array}$ & 45 & Phase II & NSCLC & 4 & Oligoprogressive (N.S.) & N.S. & N.S. & N.S. & Pembrolizumab \\
\hline $\begin{array}{l}\text { Hubbeling et al. } \\
\text { (2018) [22] }\end{array}$ & 35 & Retrospective & NSCLC & 10 & $\begin{array}{l}\text { Oligoprogressive } \\
\text { (Brain) }\end{array}$ & N.S. & N.S. & N.S. & $\begin{array}{l}\text { Nivolumab, } \\
\text { Atezolizumab, } \\
\text { Pembrolizumab }\end{array}$ \\
\hline $\begin{array}{l}\text { Verma et al. } \\
\text { (2018) [16] }\end{array}$ & 41 & Retrospective & NSCLC & N.S. & $\begin{array}{l}\text { Oligoprogressive } \\
\text { (Extracranial) }\end{array}$ & N.S. & $50 / 4$ & 112,5 & Pembrolizumab \\
\hline
\end{tabular}

${ }^{\mathrm{a} A l p h a / B e t a} 10 ;$ N.S. Not specified

and 20.4 months. Upon progression, only three of 47 measurable lesions recurred within the SBRT field [23].

Qiu et al. analyzed data from 46 patients, treated with local therapies (all but two with RT) and continuing the same TKI. Twenty-four (52.2\%) patients were treated for brain metastases, 16 (34.8\%) patients for lung metastases, and 6 patients for bone metastases. The median overall and progression-free survival after the local treatment were 13.0 and 7.0 months, respectively. The 2 -year OS was $65.2 \%$ [24].

Borghetti et al. analyzed 106 patients treated with RT concomitant to TKIs (EGFR or ALK inhibitors). Almost half of these patients were defined as oligometastatic/oligoprogressive patients. Sites of RT were brain, bone, lung or others in $46,27,14$ and $13 \%$, respectively. OS at 1 and 2 years in oligometastatic/oligoprogressive patients were 79 and $61.8 \%$, respectively [25].

Rossi et al. reported on 131 patients experiencing disease progression during first-line Afatinib or Gefitinib. Thirty of these patients received local therapy with high dose RT and continued the same drug. Median overall survival resulted longer in these patients when compared with patients continuing TT beyond progression or patients switching to another systemic therapy $(p<$ $0.0001)$. There was also a trend towards a longer second progression-free survival (measured from the time of first progression until second progression) $(p=0.06)$ [26]. A different approach has been studied by $\mathrm{Xu}$ and colleagues. They anticipated the local consolidation in oncogene driven NSCLC patients after few months of TKI, without waiting for the unavoidable progression. Patients were divided into 3 groups: 51 patients received consolidative therapy to all residual disease, 55 patients received consolidative therapy to either primary tumor or oligometastatic sites, while 39 patients did not receive any local treatment. The median PFS was improved in the first group when compared to other groups, 20.6, 15.6 , and 13.9 months, respectively $(P<0.001)$. The median OS were $40.9,34.1$, and 30.8 months in the three groups, respectively $(\mathrm{P}<0.001)$. Of note, the difference

Table 2 Clinical outcomes by the selected studies

\begin{tabular}{|c|c|c|c|c|}
\hline $\begin{array}{l}\text { Authors } \\
\text { (year of publication) }\end{array}$ & Local Control & Distant progression free survival & Overall Survival & Toxicity \\
\hline Theelen et al. (2019) [17] & NS & 6.6 months & 15.9 months & $12>\mathrm{G} 3$ \\
\hline Lesueur et al. (2018) [20] & $64,4 \% 2 \mathrm{yr}$ & 2,7 months & 11,1 months & $14,4 \%>\mathrm{G} 3$ \\
\hline Chen et al. (2018) [15] & $88 \% 1 \mathrm{yr}$ & 2.3 months & 24,7 months & $16 \%>\mathrm{G} 3$ \\
\hline Schapira et al. (2017) [21] & $100 \% 1 \mathrm{yr}$ & N.S. & 17.6 months & $0 \geq \mathrm{G} 4$ \\
\hline Bauml et al. (2019) [19] & N.S. & 19.1 months & 41.6 months & $5>\mathrm{G} 3$ \\
\hline Hubbeling et al. (2018) [22] & N.S. & N.S. & N.S. & $9>\mathrm{G} 3$ \\
\hline Verma et al. (2018) [16] & N.S. & N.S. & N.S. & $25>\mathrm{G} 3$ \\
\hline
\end{tabular}


was statistically significant between patients treated to all residual disease, while it was not significant between patients who receive a partial local treatment and patients who did not receive any local therapy at all [27].

Finally, concerning the safety profile of the combination between EGFR or ALK inhibitor and high dose $\mathrm{RT}$, none of the available studies showed a significant increase in side effects [28].

A summary of the main studies combining high dose RT and Target Therapy is reported in Tables 3 and 4.

\section{Oligometastatic melanoma}

\section{Immunotherapy and high doses RT}

Different retrospective studies have demonstrated an OS and/or intracranial control benefit of immune checkpoint inhibitors when used in combination with SRS for the treatment of melanoma brain metastases. In their mono-institutional analysis, Qin and colleagues [32] found a trend toward improved OS in advanced melanoma patients receiving Ipilimumab and ablative radiotherapy. An increased response duration was observed when RT was delivered after immunotherapy, while toxicity rates did not undergo substantial changes.

A large retrospective analysis made at Johns Hopskins hospital [15] and including patients diagnosed with brain metastases from different primary tumors, who underwent SRS with and without concurrent therapy with Immunotherapy, found a lower incidence of new intracranial metastases in those who received the combined treatment, with favorable survival outcomes and limited side effects. These last results are consistent with the ones from Diao et colleagues [33], which found a substantial improvement in median OS for patients with brain metastases treated with SRS and Ipilimumab. Four cases $(17 \%)$ of acute neurologic toxicity $>$ G2 and 4 cases (17\%) of late radiation necrosis were reported.

The association between SRS and the anti-PD-1 Pembrolizumab also showed its efficacy in a retrospective study from MSKCC [34], with a marked reduction in the size of melanoma brain metastases at the time of first follow-up.

Concerning extracranial disease localization, Gabani et al. [35] found that the addition of SBRT to immunotherapy in an unselected patient population does not seem to be beneficial if compared with immunotherapy alone. More specifically, irradiation to bone metastasis was found to be associated with worse OS than those treated with Immunotherapy alone. The only significant association with improved OS was found for patients who received early SBRT to soft tissue metastases (at least 30 days before starting immunotherapy).

A summary of the main studies combining high dose RT and immunotherapy is reported in Tables 5 and 6.

\section{Target therapy and high-dose RT}

Wolf and colleagues [39] reported the results of one of the first prospective experiences on the association of SRS with BRAF inhibitors in the treatment of melanoma patients who developed brain metastases. Overall survival was increased in patients harboring BRAF mutation (who received both therapies) compared to BRAF-wild type patients. The combined therapy was found to be safe, with no difference in terms of intracranial

Table 3 Patients and tumor characteristics of the selected studies

\begin{tabular}{|c|c|c|c|c|c|c|c|c|c|}
\hline $\begin{array}{l}\text { Authors } \\
\text { (year of } \\
\text { publication) } \\
\text { [reference] }\end{array}$ & $\begin{array}{l}\text { Number of } \\
\text { patients } \\
\text { underwent } \\
\text { SBRT }\end{array}$ & $\begin{array}{l}\text { Type of } \\
\text { Study }\end{array}$ & $\begin{array}{l}\text { Primary } \\
\text { Tumor } \\
\text { site }\end{array}$ & $\begin{array}{l}\text { Number of } \\
\text { metastases } \\
\text { underwent to } \\
\text { SBRT (upper } \\
\text { limit) }\end{array}$ & $\begin{array}{l}\text { Type of oligometastases } \\
\text { and organ involved (liver, } \\
\text { lung, bone, nodes, brain...) }\end{array}$ & $\begin{array}{l}\text { Metastases } \\
\text { size } \\
(\mathrm{cm})\end{array}$ & $\begin{array}{l}\text { SBRT } \\
\text { (median total } \\
\text { dose/fraction) }\end{array}$ & $\begin{array}{l}\text { Biologically } \\
\text { equivalent } \\
\text { dose } \\
\text { (Median } \\
\text { value) }\end{array}$ & $\begin{array}{l}\text { Systemic } \\
\text { Therapy }\end{array}$ \\
\hline $\begin{array}{l}\text { Weickhardt et al. } \\
\text { (2012) [29] }\end{array}$ & 25 & Retrospective & NSCLC & $<=4$ & $\begin{array}{l}\text { Oligoprogressive } \\
\text { (Brain,Lung) }\end{array}$ & N.S. & $\begin{array}{l}\text { 15-54Gy, } \\
\text { median 40Gy }\end{array}$ & N.S. & $\begin{array}{l}\text { Crizotinib, } \\
\text { Erlotinib }\end{array}$ \\
\hline $\begin{array}{l}\text { lyengar et al. } \\
\text { (2014) [23] }\end{array}$ & $\begin{array}{l}24 \text { (52 } \\
\text { lesions) }\end{array}$ & Phase II & NSCLC & $<=3$ & $\begin{array}{l}\text { Oligorecurrent (Lung; } \\
\text { Liver; } \\
\text { Kidney; Bone; } \\
\text { Adrenal; } \\
\text { Mediastinum) }\end{array}$ & N.S. & $19-40 / 1-5$ & $55.1-72$ & Erlotinib \\
\hline $\begin{array}{l}\text { Borghetti et al. } \\
\text { (2019) [25] }\end{array}$ & 49 & Retrospective & NSCLC & $<=4$ & $\begin{array}{l}\text { Oligoprogressive } \\
\text { (Brain, Lung, Bone) }\end{array}$ & N.S. & $\begin{array}{l}\text { mean } 80 \text { Gy, } \\
\text { range } 60-178 \\
\text { Gy }\end{array}$ & $>60$ & N.S. \\
\hline Qiu et al. (2017) [24] & 46 & Retrospective & NSCLC & $<5$ & Oligoprogressive & N.S. & N.S. & N.S. & N.S. \\
\hline Rossi et al. (2019) [26] & 30 & Retrospective & NSCLC & N.S. & Oligoprogressive & N.S. & N.S. & N.S. & $\begin{array}{l}\text { Afatinib, } \\
\text { Gefitinib }\end{array}$ \\
\hline Weiss et al. (2019) [30] & 25 & Retrospective & NSCLC & N.S. & Oligoprogressive & N.S. & N.S. & N.S. & Erlotinib \\
\hline $\begin{array}{l}\text { Chan OSH et al. } \\
\text { (2018) [31] }\end{array}$ & 18 & Phase II & NSCLC & 34 & Oligoprogressive & N.S. & N.S. & N.S. & $\begin{array}{l}\text { TKI } \\
\text { therapy }\end{array}$ \\
\hline Xu et al. (2018) [27] & 51 & Retrospective & NSCLC & N.S. & Oligoprogressive & N.S. & $\begin{array}{l}27-21-33-37.5 / \\
1-1-3-5\end{array}$ & 65.8 & $\begin{array}{l}\text { Gefitinib, } \\
\text { Erlotinib, } \\
\text { Icotinib }\end{array}$ \\
\hline
\end{tabular}


Table 4 Clinical outcomes by the selected studies

\begin{tabular}{|c|c|c|c|c|}
\hline $\begin{array}{l}\text { Authors } \\
\text { (year of publication) [reference] }\end{array}$ & Local Control & Distant progression free survival & Overall Survival & Toxicity \\
\hline Weickhardt et al. (2012) [29] & N.S. & 6.2 months & N.S. & $2 \geq \mathrm{G} 3$ \\
\hline lyengar et al. (2014) [23] & N.S. & 14.7 months & 20.4 months & $2>\mathrm{G} 3$ \\
\hline Borghetti et al. (2019) [25] & N.S. & N.S. & 23 months & $0>\mathrm{G} 3$ \\
\hline Qiu et al. (2017) [24] & $81.4 \%$ & 7 months & 35 months & $2>\mathrm{G} 3$ \\
\hline Rossi et al. (2019) [26] & N.S. & 13.8 months & 35 months & N.S. \\
\hline Weiss et al. (2019) [30] & N.S. & 6 months & 29 months & N.S. \\
\hline Chan OSH et al. (2018) [31] & N.S. & 15 months & N.S. & $0>\mathrm{G} 3$ \\
\hline Xu et al. (2018) [27] & N.S. & 20.6 months & 40.9 months & $14 \%>\mathrm{G} 3$ \\
\hline
\end{tabular}

hemorrhage events between patients who were treated with systemic agent and those who also received SRS.

Several retrospective experiences on the combo SRStarget therapy were reported in the recent years. In their institutional analysis, Ahmed et al. [40] describe the outcomes of melanoma brain metastases treated with SRS and various systemic and targeted agents. Patients who received $\mathrm{BFAF/MEK}$ inhibitors or anti-PD-1/anti-CTLA4 therapies had improved OS over patients who were treated with conventional chemotherapy on multivariate analysis from the date of SRS; significant difference was also noted on the rate of distant metastases control.

Gaudy Marqueste [41] provided other insights on the safety of the association between SRS and BRAF inhibitors. According to their analysis, the authors suggest not to withhold concomitant administration of Vemurafenib or Dabrafenib during SRS, while this precaution can still be valid in the case of other radiotherapy techniques, including Whole Brain Radiotherapy (WBRT), which implicate larger areas of healthy brain irradiation.

However, these data are not concordant with those reported by other authors. In fact, increased hemorrhage risk was noted by Ly et al. [42] in a subgroup of melanoma patients metastatic to the brain who received SRS together with BRAF inhibitors, despite the improved local control rates. Patel et al. noticed higher rates of both symptomatic and radiographic radiation necrosis in the same setting of patients [43].

We currently have fewer data concerning the role of SBRT in patients diagnosed with extracranial metastatic melanoma and undergoing BRAF inhibitors. Franceschini et al. [44] have reported that such therapeutic strategy is feasible and well tolerated, even though

Table 5 Patients and tumor characteristics of the selected studies Melanoma and Immunotherapy

\begin{tabular}{|c|c|c|c|c|c|c|c|c|c|}
\hline $\begin{array}{l}\text { Authors } \\
\text { (year of publication) } \\
\text { [reference] }\end{array}$ & $\begin{array}{l}\mathrm{N} \text { of pts } \\
\text { underwent } \\
\text { SBRT }\end{array}$ & $\begin{array}{l}\text { Type of } \\
\text { study }\end{array}$ & $\begin{array}{l}\text { Primary } \\
\text { tumor }\end{array}$ & $\begin{array}{l}\mathrm{N} \text { of } \mathrm{mts} \\
\text { underwent } \\
\text { to SBRT }\end{array}$ & $\begin{array}{l}\text { Type of } \\
\text { Oligometases } \\
\text { and organ } \\
\text { involved }\end{array}$ & $\begin{array}{l}\text { Median total } \\
\text { dose per } \\
\text { fraction }\end{array}$ & BED & $\begin{array}{l}\text { Systemic } \\
\text { Therapy }\end{array}$ & $\begin{array}{l}\text { Mts size }(\mathrm{cm}) \text {, } \\
\text { median }\end{array}$ \\
\hline $\begin{array}{l}\text { Gabani } \\
2018 \text { [35] }\end{array}$ & $\begin{array}{l}77 \text { (288 received } \\
\text { RT generically) }\end{array}$ & retrospective & Melanoma & & $\begin{array}{l}\text { Extracranial } \\
\text { (bone, soft } \\
\text { tissues, lung..) }\end{array}$ & 30 Gy $(5 f x)$ & & $\begin{array}{l}\text { Ipi, Pembro, } \\
\text { Nivo, II-2, } \\
\text { Vaccines }\end{array}$ & N/A \\
\hline $\begin{array}{l}\text { Stera } 2018 \\
{[36]}\end{array}$ & $\begin{array}{l}48^{\mathrm{a}} \text { (35 received } \\
\mathrm{ICI})\end{array}$ & retrospective & Melanoma & 250 & $\begin{array}{l}\text { Brain, Extracranial } \\
\text { (32pts.) }\end{array}$ & $18 \mathrm{~Gy}$ & $\begin{array}{l}\text { BED10 } \\
50.4 \text { Gy }\end{array}$ & $\mathrm{ICl}, \mathrm{BRAFi}$ & $\begin{array}{l}0.23 \mathrm{~cm} 3 \\
\text { (per lesion) }\end{array}$ \\
\hline $\begin{array}{l}\text { Liniker } 2016 \\
\text { [37] }\end{array}$ & 35 & retrospective & Melanoma & & Brain or Extracranial & & & Anti-PD1 & \\
\hline Qin 2015 [32] & 21 & retrospective & Melanoma & N.S. & Brain & & & Ipi & \\
\hline Diao 2018 [33] & $51^{b}$ & retrospective & Melanoma & 155 & Brain & 20 Gy & & Ipi & $0.27 \mathrm{~cm} 3$ \\
\hline $\begin{array}{l}\text { Anderson } 2017 \\
\text { [34] }\end{array}$ & $\begin{array}{l}18 \text { (11 SRS + } 7 \\
\text { hypoRT) }\end{array}$ & retrospective & Melanoma & 23 & Brain & $\begin{array}{l}20 \mathrm{~Gy}(1)<2 \mathrm{~cm} ; \\
18 \mathrm{~Gy}(1) \\
<3 \mathrm{~cm} ; \\
30 \mathrm{~Gy}(5) \\
>3 \mathrm{~cm}\end{array}$ & & Pembro & $1 \mathrm{~cm}(\mathrm{SRS})$ \\
\hline Chen 2017 [15] & $\begin{array}{l}260 \text { (70 melanoma } \\
\text { pts. }^{d} \text { ) }\end{array}$ & retrospective & $\begin{array}{l}\text { NSCLC, RCC, } \\
\text { Melanoma }\end{array}$ & 623 (total) & Brain & $20 \mathrm{~Gy}$ & & $\begin{array}{l}\text { Anti PD-1, } \\
\text { Anti Ctla4 }\end{array}$ & \\
\hline $\begin{array}{l}\text { Chandra } 2015 \\
\text { [38] }\end{array}$ & $47^{c}$ & retrospective & melanoma & 18 & Brain & 20Gy & & & $4 \mathrm{~cm}$ \\
\hline
\end{tabular}

including also pts. treated with BRAFi

${ }^{b} 23$ concurrently, 28 sequentially

including pts. receiving non SRS/RT

$\mathrm{d}_{\text {including those treated with WBRT }}$ 
Table 6 Clinical outcomes by the selected studies Melanoma and Immunotherapy

\begin{tabular}{|c|c|c|c|c|}
\hline $\begin{array}{l}\text { Authors (year of } \\
\text { publication) } \\
\text { [reference] }\end{array}$ & Local Control & $\begin{array}{l}\text { Progression free } \\
\text { survival }\end{array}$ & Overall Survival & Toxicity \\
\hline Gabani 2018 [35] & N/A & N/A & 15.4 mo (median) & N.S. \\
\hline Stera 2018 [36] & 1 yr LCR: 89.5\% & $\begin{array}{l}6 \mathrm{mo}: 42.3 \% \\
1 \mathrm{yr}: 25.5 \%\end{array}$ & $\begin{array}{l}6 \mathrm{mo}: 75.3 \% \\
1 \mathrm{yr}: 50.8 \% \\
2 \mathrm{yr}: 31.8 \%\end{array}$ & $\begin{array}{l}3>\mathrm{G} 2 \text { (1 autoimmune hypophysitis } \\
1 \text { autoimmune pancreatitis, } 1 \\
\text { radionecrosis) }\end{array}$ \\
\hline Liniker 2016 [37] & RR: $44 \%$ e $64 \%{ }^{b}$ & & & $\begin{array}{l}3>\mathrm{G} 2 \text { ( } 1 \text { case of radiation necrosis, } \\
2 \text { radiation dermatitis) }\end{array}$ \\
\hline Qin 2015 [32] & $\begin{array}{l}\text { Ipi before RT }>6 \text { and } 12 \\
\text { mo response duration } \\
\text { that Ipi after RT }\end{array}$ & & $\begin{array}{l}19.6 \text { mo (median) } \\
6 \text { mo: } 95.1 \% \\
1 \text { yr: } 79.7 \%\end{array}$ & $\begin{array}{l}\text { Pts. Who received Ipi after radiation } \\
\text { had fewer irAEs than those who } \\
\text { received it before radiation }\end{array}$ \\
\hline Diao 2018 [33] & $\begin{array}{l}\text { Non-concurrent Ipi: } \\
1 \mathrm{yr}, 70 \% \\
\text { Concurrent Ipi: } \\
1 \mathrm{yr}, 58 \%\end{array}$ & N.S. & $\begin{array}{l}\text { Non-concurrent Ipi: } \\
\text { Median,18.7 mo } \\
1 \text { yr, 63\% } \\
\text { Concurrent Ipi } \\
\text { Median, } 11.8 \mathrm{mo} \\
1 \mathrm{yr}, 50 \%\end{array}$ & $\begin{array}{l}\text { Acute } \\
4>\text { G2 (2 cases of cerebral oedema, } \\
2 \text { cases of cerebral hemorrhage) } \\
\text { Late } \\
4>\text { G2 (Radiation Necrosis) } \\
\text { No G5 events }\end{array}$ \\
\hline Anderson 2017 [34] & $\begin{array}{l}\text { 93\% (at the time of } \\
\text { death) }\end{array}$ & N.S. & N.S. & $\begin{array}{l}\text { No > G3 events } \\
1 \text { G2 CNS bleeding }\end{array}$ \\
\hline Chen 2017 [15] & $\begin{array}{l}\text { Non concurrent ICl: } \\
1 \text { yr } 79 \% \\
\text { Concurrent ICl: } \\
1 \text { yr } 88 \%\end{array}$ & N.S. & $\begin{array}{l}\text { Concurrent ICl: } 24.7 \text { mo } \\
\text { Non-Concurrent ICl: } 14.5 \\
\text { mo }\end{array}$ & $\begin{array}{l}3 \% \mathrm{G} 3 \text { acute CNS } \\
\text { No }>\text { G3 events }\end{array}$ \\
\hline Chandra 2015 [38] & & N.S. & 28 mo (median) & N.S. \\
\hline
\end{tabular}

anly attributable to SRS/SBRT+Immunotherapy

${ }^{\mathrm{b}} 44 \%$ response rate for lesions treated sequentially, $64 \%$ for lesions treated concurrently

${ }^{c} 2 / 4$ side effects reported in pts. who did not receive Immunotherapy

survival outcomes remain insufficient; however, LC of the irradiated lesions showed a significant impact on OS.

A summary of the main studies combining high dose RT and Target Therapy is reported in Tables $7 \mathrm{a}, \mathrm{b}$.

\section{Oligometastatic renal cell carcinoma (mRCC) Immunotherapy and high doses RT}

Clinical evidences reporting on the combination of SBRT with Immunotherapy in mRCC are poor. Xie et al. [48] showed a systemic complete response to SBRT and Pembrolizumab in a patient affected by mRCC. SBRT consisted in the administration of 4 consecutive fractions up to a total dose of $32 \mathrm{~Gy}$ to a mediastinal enlarged lymph node compressing the esophagus. Matsushita et al. [49] recently reported on two patients with $\mathrm{mRCC}$ who received Nivolumab combined with external irradiation and obtained a marked reduction of metastatic diseases, including non-irradiated lesions, after being refractory to prior treatment with multiple targeted agents. Taken together, these experiences could suggest that it might be worthwhile to consider the addition of SBRT for oligometastatic RCC patients treated with checkpoint inhibitors, due to the additive or synergistic effects of this combination.

\section{Target therapy and high doses $R T$}

The available experiences regarding target therapies and high doses RT included both brain and extracranial
mRCC. Cochran et al. [50] demonstrated a better local control for combined approach when compared to local therapy without targeted agents. In fact, the 1-year local control was 93.3 and $60 \%$ for patients treated with and without targeted agents, respectively. Contrarily, Verma et al. [51] has observed no improvement of local control with TKIs added to local brain therapy (surgery, SRS). Different patient populations across the studies $[50,51]$ (patients with brain metastases at relapse in the Verma series), well reflected in very different median survival rates (5.4 and 16.6 months, in Verma and Cochran series, respectively), might at least partially explain these contradictory results.

The studies on extracranial mRCC are not conclusive about the potential benefit of adding SRT to target therapy. In a recent phase I/II study including 13 patients treated with Pazopanib and SBRT local control and response rates outside the radiation field were good but seemed not to be superior when compared to SBRT or Pazopanib in monotherapy [52]. Contrarily, Dengina et al. [53] observed in a small phase 1b Volga Study (VEGFR inhibitor or mTOR inhibitor or checkpoint inhibitors and SRT) that the difference in response in the target and control metastases evaluated by a mean size of the lesions before and at 2 months after SBRT was statistically significant $(p<0.01)$. Miller et al. [54] demonstrated in the multivariate competing risks regression 


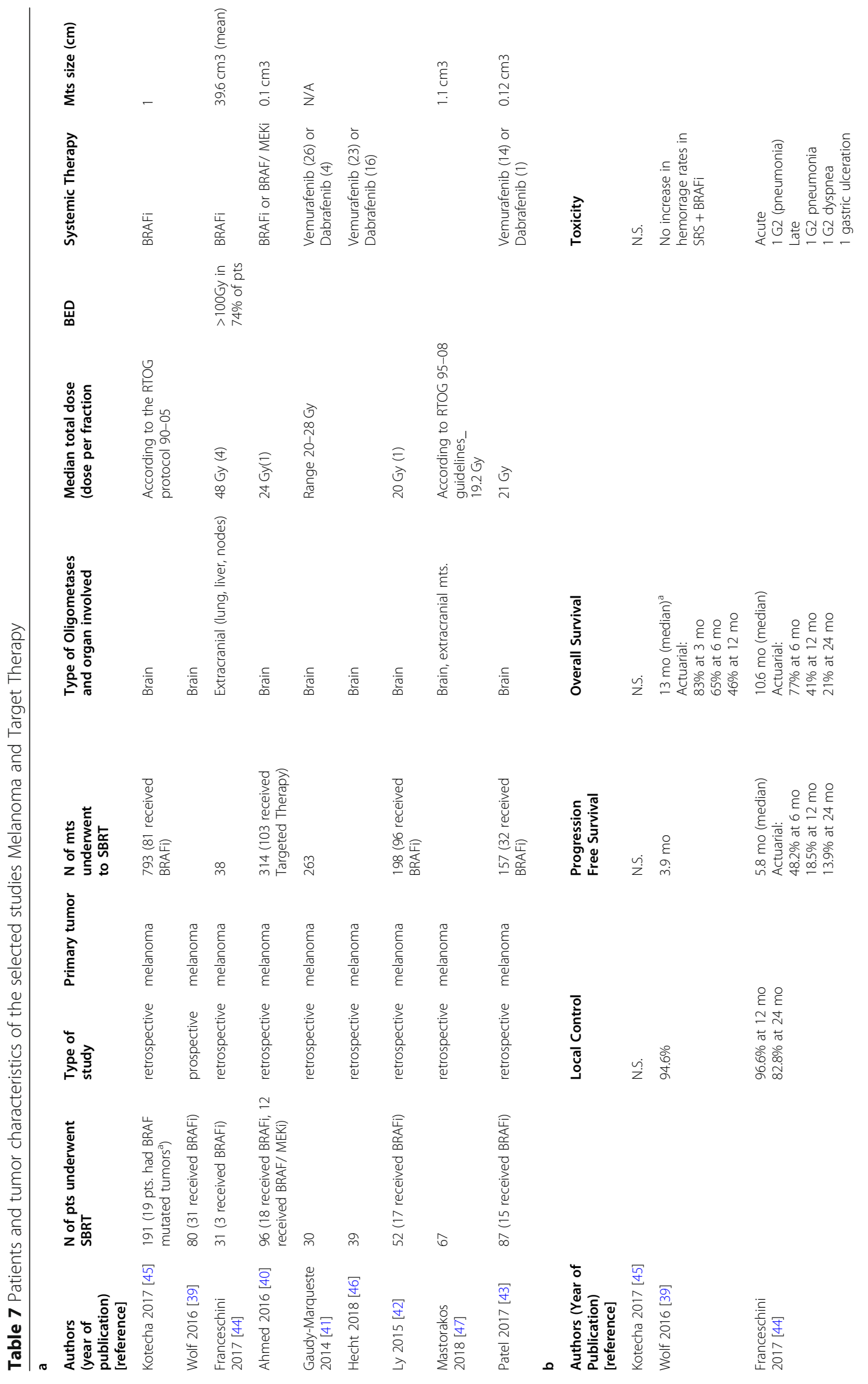




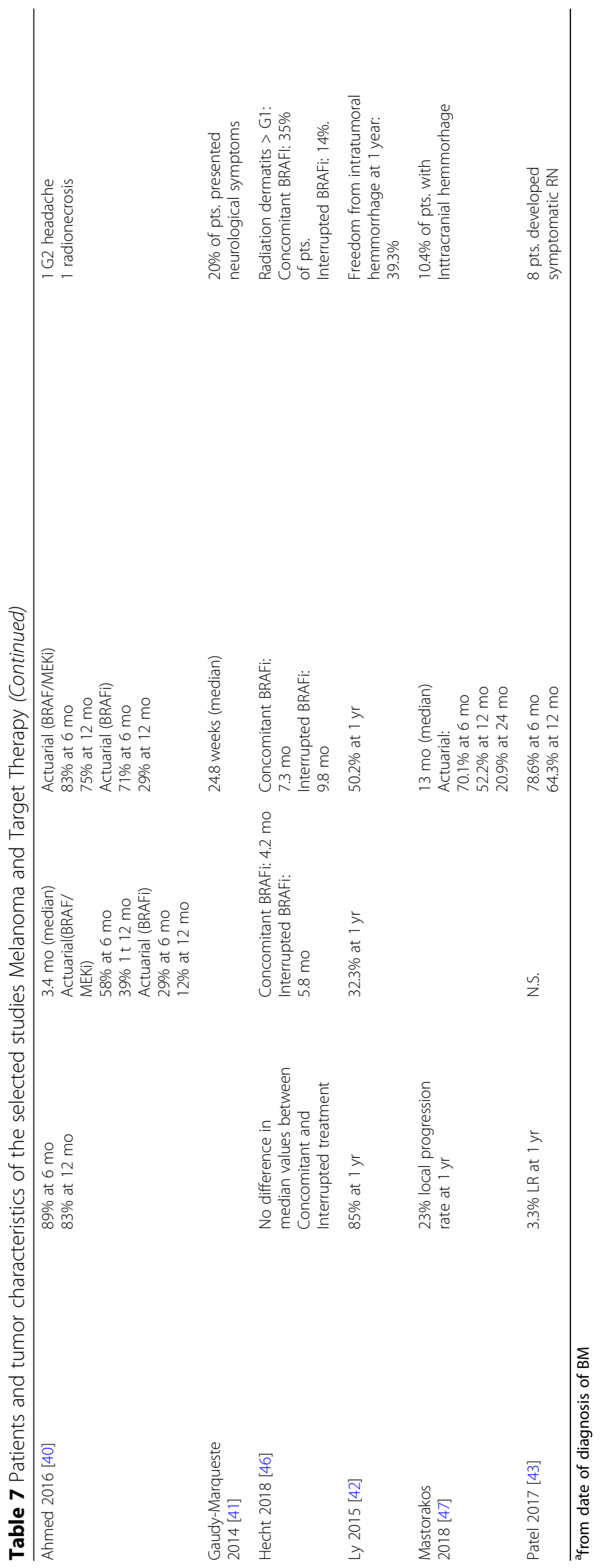




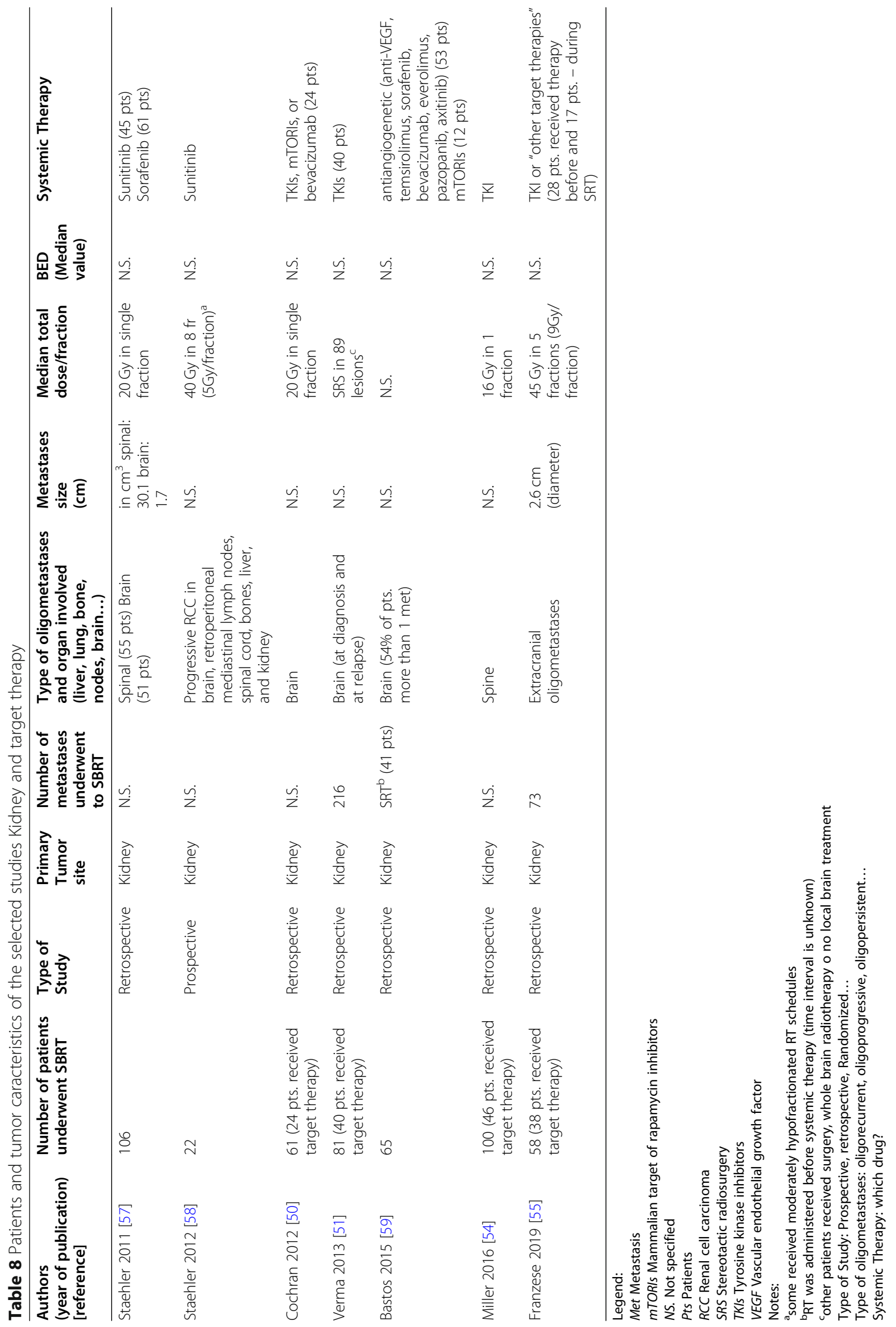


Table 9 Clinical outcomes by the selected studies Kidney and target therapy

\begin{tabular}{|c|c|c|c|c|}
\hline $\begin{array}{l}\text { Authors } \\
\text { (year of publication) } \\
\text { [reference] }\end{array}$ & Local Control & $\begin{array}{l}\text { Distant progression } \\
\text { free survival }\end{array}$ & Overall Survival & Toxicity \\
\hline Staehler 2011 [57] & $98 \%$ at 15 months & N.S. & $\begin{array}{l}\text { 17.4 months (spinal lesions) } \\
11.1 \text { months (brain lesions) }\end{array}$ & $\begin{array}{l}2 \text { pts.: asymptomatic } \\
\text { tumour haemorrhage after } \\
\text { SRS (G2) } \\
3 \text { pts.: convulsions (G2) }\end{array}$ \\
\hline Staehler 2012 [58] & $\begin{array}{l}\text { NS ( } 1 \text { case of PD at first } \\
\text { evaluation at } 3 \text { months, } \\
\text { other patients remission } \\
\text { or stable disease) }\end{array}$ & N.S. & $65 \%$ at 2 years & No G3 during combination \\
\hline Cochran 2012 [50] & $\begin{array}{l}74 \% \text { at } 1 \text { year } \\
40 \% \text { at } 3 \text { years } \\
\text { (better for combined therapy: } \\
1 \text { year LC was } 93.3 \text { and } 60 \% \\
\text { for patients treated with and } \\
\text { without targeted agents, } \\
\text { respectively) }\end{array}$ & N.S. & $\begin{array}{l}38 \% \text { at } 1 \text { year, } \\
9 \% \text { at } 3 \text { years } \\
\text { (median survival } 16.6 \text { months } \\
\text { for pts. treated with target } \\
\text { therapy) }\end{array}$ & $\begin{array}{l}6 \text { pts.: brain edema or necrosis } \\
\text { ( } 3 \text { of them received target } \\
\text { therapy) } \\
2 \text { brain hemorrhage }\end{array}$ \\
\hline Verma 2013 [51] & $\begin{array}{l}75.6 \% \text { at } 1 \text { year in pts. treated } \\
\text { with SRS } \\
\text { LC was statistically superior } \\
\text { in lesions managed with } \\
\text { surgery or SRS vs. the no } \\
\text { local therapy. } \\
\text { No improvement of LC with } \\
\text { TKIs added to local therapy } \\
\text { (surgery, SRS) }\end{array}$ & N.S. & 5.4 months (all pts) & $\begin{array}{l}4 \text { pts.: radionecrosis } \\
\text { ( } 2 \text { of them in the TKI group } \\
\text { and } 2 \text { in the non-TKI group) }\end{array}$ \\
\hline Bastos 2015 [59] & N.S. & N.S. & 12.2 months & $\begin{array}{l}5 \text { pts. (8\%): neurological } \\
2 \text { pts.: brain necrosis } \\
3 \text { pts.: brain hemorrhage }\end{array}$ \\
\hline Miller 2016 [54] & $\begin{array}{l}\text { Subgroup SRS + TKI: } 94 \% \\
\text { at } 1 \text { year }\end{array}$ & N.S. & N.S. & $\begin{array}{l}\text { No G3 in TKI + SRS pts., } \\
\text { the incidence of post-SRS vertebral } \\
\text { fracture (overall } 21 \% \text { ) and pain flare } \\
\text { (overall } 17 \% \text { ) were similar across } \\
\text { cohorts (TKI, SRS alone, TKI + SRS) }\end{array}$ \\
\hline Franzese 2019 [55] & $90.2 \%$ at 1 and 1.5 year & N.S. & $\begin{array}{l}100 \% \text { at } 1 \text { year } \\
83 \% \text { at } 5 \text { years }\end{array}$ & No G3 acute or late toxicity \\
\hline
\end{tabular}

Notes and legend:

LC Local control

NS Not specified

$P D$ Progressive disease

Pts Patients

SRS Stereotactic radiosurgery (single fraction)

TKIs Tyrosine kinase inhibitors

that concurrent first-line TKI treatment was independently associated with a local control benefit (HR 0.21, $p=0.04$ ), while patients treated with TKIs alone experienced an increased rate of local failure (HR 2.43, $p=$ 0.03). Franzese et al. [55] showed in univariate and multivariable analyses that metachronous and single metastasis but non addition of target therapy predicted better progression-free survival. However, when the analysis was restricted to cells clear RCC cases only, target therapy performed before SBRT improved local control (HR $0.15,95 \%$ CI $0.026-0.085, p=0.032$ ), suggesting different biological response of cell clear RCC to the combination of SBRT and targeted agents.

There are several ongoing or just completed prospective studies on SBRT for oligometastatic RCC [56].
A summary of the main studies combining high dose RT and Target Therapy is reported in Tables 8 and 9.

\section{Conclusions}

The therapeutic scenario of oligometastatic diseases has dramatically changed during the recent years, thanks to the introduction of the so-called metastases-directed therapy (SBRT) in combination with standard of care drugs [60]. The scientific community has focusing own interest to explore the possibility to combine new agents with SBRT to improve the therapeutic window.

Concerning the combination between SBRT and Immunotherapy, the correct sequence of remains uncertain, and seems to be drug-dependent: best results were seen when CTLA-4 was given before SBRT while 
inhibition of the PD-1 axis has been proved to be most efficient when given in close temporal relation to the radiation treatment. Secondly, SBRT should be carefully taken into account as the most currently employed such as intensity modulated radiotherapy leads to a low-dose bath to a large part of the body, thus potentially interfering with the priming process of $\mathrm{T}$ lymphocytes - the most radiosensitive cells in the body - and its memory functions. Last, optimal patients' selection is crucial to expect substantial benefits to SBRT/Immunotherapy combination and, among several factors, a low tumor burden seems to be the most relevant, thus making the oligometastatic disease the ideal setting for the use of combination therapies with immunological drugs.

Regarding target therapy and SBRT a field of interest is represented by the so-called oligoprogressed disease during targeted therapies. In fact, it is common to observe isolated disease progression in few sites, usually one to three, in a scenario of disease controlled by systemic therapy. In this last clinical scenario, the main aim of SBRT is the prolongation of efficacy of the existing target therapy, the delay of the switch to other systemic therapies and the improvement of patients'outcome modifying the natural history of the disease.

In the setting of oligometastatic disease, the combination of these new drugs with ablative doses of RT to limited tumor sites has brought a momentous improvement in disease control rates.

\section{Abbreviations \\ OAR: Organs at risk; SBRT: Stereotactic body radiation therapy; VEGF: Vascular endothelial growth factor; AE: Abscopal effect; CTLA-4: Cytotoxic T- lymphocyte-associated Protein 4; PD-1: Programmed cell death protein 1; HR: Hazard ratio; mTORIs: Mammalian target of rapamycin inhibitors; RCC: Renal cell carcinoma; RT: Radiotherapy; SBRT: Stereotactic radiotherapy; SRS: Stereotactic radiosurgery (single fraction SRT); TKIs: Tyrosine kinase inhibitors; VEGFR: Receptor of vascular endothelial growth factor}

\section{Acknowledgements}

None.

\section{Authors' contributions}

-Conception and design: FA, BAJF, MS, RM. -Data collection and literature research: SC, MT, AL. -Manuscript drafting: RM, DF, ST, GM, ARF, SA. -Final review: all Authors. The author(s) read and approved the final manuscript.

\section{Funding}

No fundings.

\section{Availability of data and materials}

Not applicable.

Ethics approval and consent to participate

Not applicable.

\section{Consent for publication}

All Authors agree for publication.

Competing interests

Nothing to declare.

\section{Author details}

${ }^{1}$ IRCCS, Advanced Radiation Oncology Department, Sacro Cuore Don Calabria Hospital, Negrar di Valpolicella, Verona, Italy. ${ }^{2}$ Department of Radiation Oncology IEO, European Institute of Oncology IRCCS, Milan, Italy. ${ }^{3}$ Department of Oncology and Hemato-oncology University of Milan, Milan, Italy. ${ }^{4}$ Radiotherapy and Radiosurgery Department, Humanitas Cancer Center, Rozzano, Milan, Italy. ${ }^{5}$ KABEG Klinikum Klagenfurt, Institute of Radiation Oncology, Klagenfurt am Wörthersee, Austria. ${ }^{6}$ Radiation Oncology, Fondazione IRCCS Policlinico San Matteo, Pavia, Italy. ${ }^{7}$ Faculty of Medicine, School of Health Sciences, University of Thessaly, University Hospital of Larissa, Biopolis, Larisa, Greece. ${ }^{8}$ Radiation Oncology Unit, Department of Medicine, Surgery and Neuroscience, University of Siena, Siena, Italy. ${ }^{9}$ Department of Radiation Oncology, University Hospital, LMU Munich, Munich, Germany. ${ }^{10}$ Department of Radiation Oncology, Policlinico S. Gerardo and University of Milan "Bicocca", Milan, Italy. "University of Brescia, Brescia, Italy.

Received: 28 January 2020 Accepted: 22 April 2020

Published online: 04 May 2020

\section{References}

1. Hellman S, Weichselbaum RR. Oligometastases. J Clin Oncol. 1995;13(1):810. https://doi.org/10.1200/JCO.1995.13.1.8.

2. Alongi F, Arcangeli S, Filippi AR, Ricardi U, Scorsetti M. Review and uses of stereotactic body radiation therapy for oligometastases. Oncologist. 2012; 17(8):1100-7. https://doi.org/10.1634/theoncologist.2012-0092.

3. Mazzola R, Corradini S, Gregucci F, Figlia V, Fiorentino A, Alongi F. Role of radiosurgery/stereotactic radiotherapy in Oligometastatic disease: brain Oligometastases. Front Oncol. 2019;9:206. https://doi.org/10.3389/fonc.2019. 00206.

4. Alongi F, Mazzola R, Figlia V, Guckenberger M. Stereotactic body radiotherapy for lung oligometastases: literature review according to PICO criteria. Tumori. 2018;104(3):148-56. https://doi.org/10.1177/ 0300891618766820.

5. Mazzola R, Fersino S, Ferrera G, Targher G, Figlia V, Triggiani L, et al. Stereotactic body radiotherapy for lung oligometastases impacts on systemic treatment-free survival: a cohort study. Med Oncol. 2018;35(9):121. https://doi.org/10.1007/s12032-018-1190-8.

6. Zeng J, Baik C, Bhatia S, Mayr N, Rengan R. Combination of stereotactic ablative body radiation with targeted therapies. Lancet Oncol. 2014;15: e426-34. https://doi.org/10.1016/S1470-2045(14)70026-9.

7. Park HJ, Griffin RJ, Hui S, Levitt SH, Song CW. Radiation-induced vascular damage in tumors: implications of vascular damage in ablative hypofractionated radiotherapy (SBRT and SRS). Rad Res. 2012;177:311-27. https://doi.org/10.1667/rr2773.1.

8. Hellevik T, Martinez-Zubiaurre I. Radiotherapy and the tumor stroma: the importance of dose and fractionation. Front Oncol. 2014;4:1. https://doi.org/ 10.3389/fonc.2014.00001.

9. Andisheh B, Edgren M, Belkic D, Mavroidis P, Brahme A, Lind BK. A comparative analysis of radiobiological models for cell surviving fractions at high doses. Technol Cancer Res Treat. 2013;12:183-92. https://doi.org/10. 7785/tcrt.2012.500306.

10. Weichselbaum RR, Liang H, Deng L, Fu YX. Radiotherapy and immunotherapy: a beneficial liaison? Nat Rev Clin Oncol. 2017;14:365-79. https://doi.org/10.1038/nrclinonc.2016.211.

11. Ngwa W, Irabor OC, Schoenfeld JD, Hesser J, Demaria S, Formenti SC. Using immunotherapy to boost the abscopal effect. Nat Rev Cancer. 2018;18:31322. https://doi.org/10.1038/nrc.2018.6.

12. Buchwald ZS, Wynne J, Nasti TH, Zhu S, Mourad WF, Yan W, et al. Radiation, immune checkpoint blockade and the Abscopal effect: a critical review on timing. Dose and Fractionation. Front Oncol. 2018;8:612. https://doi.org/10. 3389/fonc.2018.

13. Twyman-Saint Victor C, Rech AJ, Maity A, Rengan R, Pauken KE, Stelekati E, et al. Radiation and dual checkpoint blockade activate nonredundant immune mechanisms in cancer. Nature. 2015;520:373-7. https://doi.org/10. 1038/nature14292.

14. Dovedi SJ, Adlard AL, Lipowska-Bhalla G, McKenna C, Jones S, Cheadle EJ, et al. Acquired resistance to fractionated radiotherapy can be overcome by concurrent PD-L1 blockade. Cancer Res. 2014;74:5458-68. https://doi.org/10. 1158/0008-5472.CAN-14-1258. 
15. Chen L, Douglass J, Kleinberg L, Ye X, Marciscano AE, Forde PM, et al. Concurrent immune checkpoint inhibitors and stereotactic radiosurgery for brain metastases in non-small cell lung Cancer, melanoma, and renal cell carcinoma. Int J Radiat Oncol Biol Phys. 2018;100(4):916-25. https://doi.org/ 10.1016/j.jijrobp.2017.11.041.

16. Verma V, Cushman TR, Selek U, Tang C, Welsh JW. Safety of combined immunotherapy and thoracic radiation therapy: analysis of 3 singleinstitutional phase I/II trials. Int J Radiat Oncol Biol Phys. 2018;101(5):1141-8. https://doi.org/10.1016/j.jijobp.2018.04.054

17. Theelen WSME, Peulen HMU, Lalezari F, van der Noort V, de Vries JF, Aerts JGJV, et al. Effect of Pembrolizumab after stereotactic body radiotherapy vs Pembrolizumab alone on tumor response in patients with advanced nonsmall cell lung Cancer: results of the PEMBRO-RT phase 2 randomized clinical trial. JAMA Oncol. 2019. https://doi.org/10.1001/jamaoncol.2019.1478.

18. Dewan MZ, Galloway AE, Kawashima N, Dewyngaert JK, Babb JS, Formenti SC, et al. Fractionated but not single-dose radiotherapy induces an immune-mediated abscopal effect when combined with anti-CTLA-4 antibody. Clin Cancer Res. 2009;15(17):5379-88. https://doi.org/10.1158/ 1078-0432.CCR-09-0265.

19. Bauml JM, Mick R, Ciunci C, Aggarwal C, Davis C, Evans T, et al. Pembrolizumab after completion of locally ablative therapy for Oligometastatic non-small cell lung Cancer: a phase 2 trial. JAMA Oncol. 2019. https://doi.org/10.1001/jamaoncol.2019.

20. Lesueur P, Escande A, Thariat J, Vauléon E, Monnet I, Cortot A, et al. Safety of combined PD-1 pathway inhibition and radiation therapy for non-smallcell lung cancer: a multicentric retrospective study from the GFPC. Cancer Med. 2018;7(11):5505-13. https://doi.org/10.1002/cam4.1825.

21. Schapira E, Hubbeling H, Yeap BY, Mehan WA Jr, Shaw AT, Oh K, et al. Improved overall survival and Locoregional disease control with concurrent PD-1 pathway inhibitors and stereotactic radiosurgery for lung Cancer patients with brain metastases. Int J Radiat Oncol Biol Phys. 2018;101(3): 624-9. https://doi.org/10.1016/j.jijobp.2018.02.175.

22. Hubbeling HG, Schapira EF, Horick NK, Goodwin KEH, Lin JJ, Oh KS, et al Safety of combined PD-1 pathway inhibition and intracranial radiation therapy in non-small cell lung Cancer. J Thorac Oncol. 2018;13(4):550-8. https://doi.org/10.1016/j.jtho.2018.01.012.

23. lyengar P, Kavanagh BD, Wardak Z, Smith I, Ahn C, Gerber DE, et al. Phase II trial of stereotactic body radiation therapy combined with erlotinib for patients with limited but progressive metastatic non-small-cell lung cancer. J Clin Oncol. 2014;32:3824-30. https://doi.org/10.1200/JCO.2014.56.7412.

24. Qiu B, Liang Y, Li QW, Liu G, Wang F, Chen Z, et al. Local therapy for Oligoprogressive disease in patients with advanced stage non-small-cell lung Cancer harboring epidermal growth factor receptor mutation. Clin Lung Cancer. 2017;18(6):e369-73. https://doi.org/10.1016/j.cllc.2017.04.002.

25. Borghetti $P$, Bonù ML, Giubbolini R, Levra NG, Mazzola R, Perna M, et al. Concomitant radiotherapy and TKI in metastatic EGFR- or ALK-mutated nonsmall cell lung cancer: a multicentric analysis on behalf of AIRO lung cancer study group. Radiol Med. 2019;124(7):662-70. https://doi.org/10.1007/ s11547-019-00999-w.

26. Rossi S, Finocchiaro G, Noia VD, Bonomi M, Cerchiaro E, Rose F, et al. Survival outcome of tyrosine kinase inhibitors beyond progression in association to radiotherapy in oligoprogressive EGFR-mutant non-small-cell lung cancer. Future Oncol. 2019;15(33):3775-82. https://doi.org/10.2217/fon2019-0349.

27. Xu Q, Zhou F, Liu H, Jiang T, Li X, Xu Y, et al. Consolidative local ablative therapy improves the survival of patients with synchronous oligometastatic NSCLC harboring EGFR activating mutation treated with first-line EGFR-TKIs. J Thorac Oncol. 2018;13(9):1383-92. https://doi.org/10.1016/j.jtho.2018.05.019.

28. Kroeze SG, Fritz C, Hoyer M, Lo SS, Ricardi U, Sahgal A, et al. Toxicity of concurrent stereotactic radiotherapy and targeted therapy or immunotherapy: a systematic review. Cancer Treat Rev. 2017:53:25-37. https://doi.org/10.1016/j.ctrv.2016.11.013.

29. Weickhardt AJ, Scheier B, Burke JM, Gan G, Lu X, Bunn PA Jr, et al. Local ablative therapy of oligoprogressive disease prolongs disease control by tyrosine kinase inhibitors in oncogene-addicted non-small-cell lung cancer J Thorac Oncol. 2012;7(12):1807-14. https://doi.org/10.1097/JTO. Ob013e3182745948.

30. Weiss J, Kavanagh B, Deal A, Villaruz L, Stevenson J, Camidge R, et al. Phase II study of stereotactic radiosurgery for the treatment of patients with oligoprogression on erlotinib. Cancer Treat Res Commun. 2019;19:100126. https://doi.org/10.1016/j.ctarc.2019.100126.
31. Chan OSH, Lam KC, Li J, et al. ATOM: A Phase II Study to Assess Efficacy of Preemptive Local Ablative Therapy to Residual Oligometastases After EGFR TKI. J Thorac Oncol. 2018;13(10):S336. https://doi.org/10.1016/j.jtho.2018.08.270.

32. Qin R, Olson A, Singh B, Thomas S, Wolf S, Bhavsar NA, et al. Safety and efficacy of radiation therapy in advanced melanoma patients treated with Ipilimumab. Int J Radiat Oncol Biol Phys. 2016;96(1):72-7. https://doi.org/10. 1016/j.jijrobp.2016.04.017.

33. Diao K, Bian SX, Routman DM, Yu C, Ye JC, Wagle NA, et al. Stereotactic radiosurgery and ipilimumab for patients with melanoma brain metastases: clinical outcomes and toxicity. J Neuro-Oncol. 2018;139(2):421-9. https://doi. org/10.1007/s11060-018-2880-y.

34. Anderson ES, Postow MA, Wolchok JD, Young RJ, Ballangrud $\AA$, Chan TA, et al. Melanoma brain metastases treated with stereotactic radiosurgery and concurrent pembrolizumab display marked regression; efficacy and safety of combined treatment. J Immunother Cancer. 2017;5(1):76. https://doi.org/10. 1186/s40425-017-0282-x.

35. Gabani P, Robinson CG, Ansstas G, Johanns TM, Huang J. Use of extracranial radiation therapy in metastatic melanoma patients receiving immunotherapy. Radiother Oncol. 2018;127(2):310-7. https://doi.org/10. 1016/j.radonc.2018.02.022.

36. Stera S, Balermpas P, Blanck O, Wolff R, Wurster S, Baumann R, et al. Stereotactic radiosurgery combined with immune checkpoint inhibitors or kinase inhibitors for patients with multiple brain metastases of malignant melanoma. Melanoma Res. 2019;29(2):187-95. https://doi.org/10.1097/CMR. 0000000000000542

37. Liniker E, Menzies AM, Kong BY, Cooper A, Ramanujam S, Lo S, et al. Activity and safety of radiotherapy with anti-PD-1 drug therapy in patients with metastatic melanoma. Oncoimmunology. 2016;5(9):e1214788. https://doi. org/10.1080/2162402X.2016.1214788.

38. Chandra RA, Wilhite TJ, Balboni TA, Alexander BM, Spektor A, Ott PA, et al. A systematic evaluation of abscopal responses following radiotherapy in patients with metastatic melanoma treated with ipilimumab. Oncoimmunology. 2015;4(11):e1046028. https://doi.org/10.1080/2162402X. 2015.1046028.

39. Wolf A, Zia S, Verma R, Pavlick A, Wilson M, Golfinos JG, et al. Impact on overall survival of the combination of BRAF inhibitors and stereotactic radiosurgery in patients with melanoma brain metastases. J Neuro-Oncol. 2016;127(3):607-15. https://doi.org/10.1007/s11060-016-2072-6.

40. Ahmed KA, Abuodeh YA, Echevarria MI, Arrington JA, Stallworth DG, Hogue $C$, et al. Clinical outcomes of melanoma brain metastases treated with stereotactic radiosurgery and anti-PD-1 therapy, anti-CTLA-4 therapy, BRAF/ MEK inhibitors, BRAF inhibitor, or conventional chemotherapy. Ann Oncol. 2016;27(12):2288-94. https://doi.org/10.1093/annonc/mdw417.

41. Gaudy-Marqueste C, Carron R, Delsanti C, Loundou A, Monestier S, Archier E, et al. On demand gamma-knife strategy can be safely combined with BRAF inhibitors for the treatment of melanoma brain metastases. Ann Oncol. 2014;25(10):2086-91. https://doi.org/10.1093/annonc/mdu266.

42. Ly D, Bagshaw HP, Anker CJ, Tward JD, Grossmann KF, Jensen RL, et al. Local control after stereotactic radiosurgery for brain metastases in patients with melanoma with and without BRAF mutation and treatment. J Neurosurg. 2015;123(2):395-401. https://doi.org/10.3171/2014.9.JNS141425.

43. Patel KR, Chowdhary M, Switchenko JM, Kudchadkar R, Lawson DH, Cassidy $\mathrm{RJ}$, et al. BRAF inhibitor and stereotactic radiosurgery is associated with an increased risk of radiation necrosis. Melanoma Res. 2016;26(4):387-94. https://doi.org/10.1097/CMR.0000000000000268

44. Franceschini D, Franzese C, De Rose F, Navarria P, D'Agostino GR, Comito T, et al. Role of extra cranial stereotactic body radiation therapy in the management of stage IV melanoma. Br J Radiol. 2017;90(1077):20170257. https://doi.org/10.1259/bjr.20170257.

45. Kotecha R, Miller JA, Venur VA, Mohammadi AM, Chao ST, Suh JH, et al. Melanoma brain metastasis: the impact of stereotactic radiosurgery, BRAF mutational status, and targeted and/or immune-based therapies on treatment outcome. J Neurosurg. 2018;129(1):50-9. https://doi.org/10.3171/ 2017.1.JNS162797.

46. Hecht M, Meier F, Zimmer L, Polat B, Loquai C, Weishaupt C, et al. Clinical outcome of concomitant vs interrupted BRAF inhibitor therapy during radiotherapy in melanoma patients. Br J Cancer. 2018;118(6):785-92. https:// doi.org/10.1038/bjc.2017.489.

47. Mastorakos P, Xu Z, Yu J, Hess J, Qian J, Chatrath A, et al. BRAF V600 mutation and BRAF kinase inhibitors in conjunction with stereotactic radiosurgery for intracranial melanoma metastases: a multicenter 
retrospective study. Neurosurgery. 2019;84(4):868-80. https://doi.org/10. 1093/neuros/nyyz203.

48. Xie G, Gu D, Zhang L, Chen S, Wu D. A rapid and systemic complete response to stereotactic body radiation therapy and pembrolizumab in a patient with metastatic renal cell carcinoma. Cancer Biol Ther. 2017;18(8): 547-51. https://doi.org/10.1080/15384047.2017.

49. Matsushita Y, Nakamura K, Furuse H, Ichinohe K, Miyake H, et al. Marked response to nivolumab combined with external radiation therapy for metastatic renal cell carcinoma: report of two cases. Int Cancer Conf J. 2018; 8(1):29-32. https://doi.org/10.1007/s13691-018-0349-7.

50. Cochran DC, Chan MD, Aklilu M, Lovato JF, Alphonse NK, Bourland JD, et al. The effect of targeted agents on outcomes in patients with brain metastases from renal cell carcinoma treated with gamma knife surgery. Neurosurg. 2012;116(5):978-83. https://doi.org/10.3171/2012.2.JNS111353.

51. Verma J, Jonasch E, Allen PK, Weinberg JS, Tannir N, Chang EL, et al. The impact of tyrosine kinase inhibitors on the multimodality treatment of brain metastases from renal cell carcinoma. Am J Clin Oncol. 2013;36(6):620-4. https://doi.org/10.1097/COC.0b013e31825d59db.

52. De Wolf K, Rottey S, Vermaelen K, Decaestecker K, Sundahl N, De Lobel L, et al. Combined high dose radiation and pazopanib in metastatic renal cell carcinoma: a phase I dose escalation trial. Radiat Oncol. 2017;12(1):157. https://doi.org/10.1186/s13014-017-0893-x.

53. Dengina N, Mitin T, Gamayunov S, Safina S, Kreinina Y, Tsimafeyeu I. Stereotactic body radiation therapy in combination with systemic therapy for metastatic renal cell carcinoma: a prospective multicentre study. ESMO Open. 2019:4(5):e000535. https://doi.org/10.1136/esmoopen-2019-000535.

54. Miller JA, Balagamwala EH, Angelov L, Suh JH, Rini B, Garcia JA, et al. Spine stereotactic radiosurgery with concurrent tyrosine kinase inhibitors for metastatic renal cell carcinoma. J Neurosurg Spine. 2016;25(6):766-74. https://doi.org/10.3171/2016.4.SPINE16229.

55. Franzese C, Franceschini D, Di Brina L, GR DA, Navarria P, Comito T, et al. Role of stereotactic body radiation therapy for the Management of Oligometastatic Renal Cell Carcinoma. J Urol. 2019;201(1):70-5. https://doi. org/10.1016/j.juro.2018.08.049.

56. Alongi F, Arcangeli S, Triggiani L, Mazzola R, Buglione di mMnale E Bastia M, Fersino $S$, et al. Stereotactic ablative radiation therapy in renal cell carcinoma: From oligometastatic to localized disease. Crit Rev Oncol Hematol. 2017;117:48-56. https://doi.org/10.1016/j.critrevonc.2017.07.004.

57. Staehler M, Haseke N, Nuhn P, Tüllmann C, Karl A, Siebels M, et al. Simultaneous anti-angiogenic therapy and single-fraction radiosurgery in clinically relevant metastases from renal cell carcinoma. BJU Int. 2011;108(5): 673-8. https://doi.org/10.1111/j.1464-410X.2010.09895.

58. Staehler M, Haseke N, Stadler T, Nuhn P, Roosen A, Stief CG, et al. Feasibility and effects of high-dose hypofractionated radiation therapy and simultaneous multi-kinase inhibition with sunitinib in progressive metastatic renal cell cancer. Urol Oncol. 2012;30(3):290-3. https://doi.org/10.1016/j. urolonc.2010.02.006.

59. Bastos DA, Molina AM, Hatzoglou V, Jia X, Velasco S, Patil S, et al. Safety and efficacy of targeted therapy for renal cell carcinoma with brain metastasis. Clin Genitourin Cancer. 2015;13(1):59-66. https://doi.org/10.1016/..lgc.2014. 06.00.

60. Palma DA, Olson R, Harrow S, Gaede S, Louie AV, Haasbeek C, et al. Stereotactic ablative radiotherapy versus standard of care palliative treatment in patients with oligometastatic cancers (SABR-COMET): a randomised, phase 2, open-label trial. Lancet. 2019;393(10185):2051-8. https://doi.org/10.1016/S0140-6736(18)32487-5.

\section{Publisher's Note}

Springer Nature remains neutral with regard to jurisdictional claims in published maps and institutional affiliations.

Ready to submit your research? Choose BMC and benefit from:

- fast, convenient online submission

- thorough peer review by experienced researchers in your field

- rapid publication on acceptance

- support for research data, including large and complex data types

- gold Open Access which fosters wider collaboration and increased citations

- maximum visibility for your research: over $100 \mathrm{M}$ website views per year

At BMC, research is always in progress.

Learn more biomedcentral.com/submissions 